\title{
POLITICAL INFLUENCE: A CULTURE IN UNIVERSITY DECISION-MAKING
}

\author{
Dr. Radhaber D. Khati
}

\section{GOVERNMENT AND POLITICIANS}

Higher educational organization, established, maintained and aided by the government in socio-economically and educationally least developed country, have come under the direct secrutiny and supervision of government. It is often argued that universities, created by Acts passed by the legislature and supported by government funds, are often financially and politically controlled by the government. Besides, appointing the chief executive of the university, the government controls the administrative and decision-making power of the university. There are some views that support this practice of political control over the administrative and decision-making affairs of the institutions of higher education. These views are based on the argument that the organizations with some type of political control can progress more easily toward the achievement of their goals (Livingstone, 1974). One of the goals of university officials is the establishment of a positive relationship between the university and the outside political world. This relationship, as Livingstone argued, determines the degree of political control over the universities. He attached political influence in the decision-making of the university into two sources: political figures and the government. The former consisting of elected officials, educated politicians and boards of education, and the latter containing central and local government bodies. The former has the power and influence to set institutional goals, policies, and overall guidelines; whereas the latter influences the means and resources of the institutions (Livingstone, 1974). The power of these political agencies to influence university decision-making is derived from the public, for they come from the people they represent. But in the case of Nepal, the elected political officials assume the control over the central and the local government bodies, and these bodies are inclined to the political decisions made by the political figures in the party/ies in power.

Politicians and bureaucrats in the government make policies and laws with regard to the formation and the proper functioning of the university. The role of politicians in making university policy decisions has been described by Baldrige (1971). According to hims, university governance runs more in a political than collegial or bureaucratic fashion, because the administrators have to "grapple with the power plays, conflicts, and rough-and-tumble politics." In a way, similar to what Baldrige described, the politicians, with the help of bureaucrats and the political-minded educators, make the policies of a university. His view of the fragmentation of interest groups within a university has relevance in the context of our university. Different interest groups, within the university organization, working as faculty, students, and the administrative staff, are often divided among themselves by their political beliefs and the formal or informal 


\section{POLITICAL INFLUENCE: A CULTURE IN UNIVERSITY}

affiliations with the respective political parties. These fragmented groups, duly supported by the respective political parties, form powerful blocks at the university through which the external power and politics exert influence (Baldrige, 1971). Therefore, a large portion of the working hours of the chief executive at the university is spent on compromise and negotiation with these powerful blocks at the university so that conflicts between administration and the power blocks could be avoided. It has been noted that the key figure in such an organization is not the President (or the Vice-chancellor), but the political leaders either in favor or against the government, who are surrounded by politically inspired staff, students and the faculty (Baldridge, 1991).

\section{OPPOSING VIEWS}

These politicians and the government bureaucrats also have potential control over the public money and the right to approve or disapprove the budget of the institution. This type of governmental control, however, is not very palatable to certain scholars. One of the proponents of the argument against government control was MacKinnon (1965), who showed his dislike the way how teachers and educators were removed from making decisions in the affairs of education, and educational decisions were made by politicians, civil servants, and various interest groups. MacKinnon believed this was "undemocratic" and would create great dependency on the part of the institution. Such dependency might kill institutional initiatives, incentives, and innovations in this type of organization. However, according to Rudolph and Rudolph (1972), if powers and resources were put in the hands of local communities that would promote responsibility and informed decision-making quality in these communities.

In many developing countries, higher education institutions become a field where politicians play their games of dispute. Conflicting political parties find it easy to mobilize their own groups of students or teachers at a university in order to affect their political objectives. In playing these political games at the university, they try to influence the intellectual sector of the country. It has further been argued that power by the politicians over the domain of education means power over the minds, talents, and opinions of the people, and that this is far more significant than power over their purse, their commerce, or their bodies (MacKinnon, 1965). Therefore, there is no other area of operation, that MacKinnon considers to be of great importance for the politicians to exercise their influence, than education.

There are opposing views regarding political control over and influence in the decision-making at the university. The argument that political influence in the decision-making at the university differs from country to country (Karol \& Ginsburg, 1980; Massialas, 1969), and from time to time (Kogan, 1984; Rudolph \& Rudolph, 1972), is not so unconvincing. The direct regulatory control over higher education institutions by the government was seen by Gore (1982) to be justifiable. This is one of the ways how larger national society influences the organization like a university. But, depending on the politics of the country, the 
TRIBHUVAN UNIVERSITY JOURNAL, VOL. XXIV, NO. 1,

mechanisms to control and influence such organizations differ from place to place and time to time (Kogan, 1984).

Rudolph and Rudolph (1972), when describing education system and influence of politics on higher education in neighboring India, stated that the influence of government on university decision-making was very strong. They reasoned that my amount of irregularities by the government may be taken as granted, because it is the responsibility of the government to monitor how the universities should run. In the context of the countries of our region, government's role as a facilitator is so closely connected with that of a controller that one cannot make a clear distinction between the two. In this respect, the Rudolphs' (1972) view is that if the government ceased to influence or control the university affairs, the university would become helpless. This would be true especially in the case of universities that need government support to grow.

\section{ROLE OF CULTURE}

The question arises as to whether organizational decisions for the solutions to the problems in the traditional societies are different from those decisions that are made for the solutions to the problems in the societies that appear to be relatively modern. If the decisions are different, is it so due to the process that differs between any two societies and the cultures? Do social settings and cultural factors in a country have any impact on the process of decision making? Hofstede's (1991) analysis with regard to cultural contexts of the country in relation to decision-making, is quite relevant. He believed that although "social anthropology" underscores the conviction that all societies, modern or traditional face the same basic problems, the process of solving problems differs from country to country. This is because the preference and process of decision making that are based on specific criteria have different dimensions in different countries. For Hofstede (1991), the social criteria on which organizational decision-making is based are concerned with:

(a) Social inequality, including the employees' relationship with the authority;

(b) Relationships between individuals and the group;

(c) Concepts of masculinity and femininity; and

(d) Ways of dealing with conflicts.

Of the criteria mentioned above, the most important one that has a bearing in organizational decision-making is concerned with the subordinate and higher authority relationship. By constitution, or the law of the country, there should not be any discrimination among the people and everyone should be treated equally regardless of caste, class, power, sex, status and wealth. However, as Hosfstede (1991) said, it is very difficult to find that reality matching the ideal. The gap between what is ideally prescribed in the constitution or in the book of law, and what is found to be operating in real practice remains wide in the countries that are less developed, not only economically and educationally but 


\section{POLITICAL INFLUENCE: A CULTURE IN UNIVERSITY}

politically. This inconsistency between ideal and the actual practice has a great bearing on the system of decision-making in an organization.

\section{PERSON, POSITION AND POWER-DISTANCE}

With regard to the cultural impact on the decision-making, Hofstede (1991) noted his concept of power distance. He differentiated big power distance from small power distance on the basis of the culture of a country. The organizational structure and the power distance between subordinates and their boss influence decision-making. There are many supervisory personnel who are structured into the hierarchy of people reporting to each other. In countries where the employees are not afraid and the bosses are not often autocratic or paternalistic, the employees express a preference for a consultative style of decision making (Hofstede, 1991). Conversely, if the employees are seen as frequently afraid of disagreeing with their bosses, and the bosses are autocratic or paternalistic, the subordinates are less likely to approach their bosses and to contradict them. In a large power distance structure within an organization, the chances are that the organizational decisions are made or influenced by the centralized authority holding political power. Nepal falls in the category of large power distance countries, because the subordinate-boss relationship is not only characterized by inequality, dependence, and polarization between the tow groups; but also by obedience and respect from the subordinate, and control from the superior. Therefore, in the system of administrative decision-making, it is not always the legitimacy of the decision maker that is gained through one's own professional expertise, but the power, might, skills, status and wealth of a superior that enable him to make decisions or influence the decision-making in an organization.

It has been argued that it is the position rather than the person in it, that is crucial in exercising power over institutional decision making (MacKinnon, 1965). Even if the positions are held by teachers, the same limitation would apply to them. Thus, no matter who is in the position, the same human behavior of exercising power and influence would be exhibited. The decisions that are appropriate to one institution may not be appropriate to another. This is particularly so in a complex educational organization like a university where no issue has a single uniform answer (Karol \& Ginsburg, 1980). Therefore, even if broader higher educational decision making issues are similar among the universities, certain specifics may be different in the making of decisions from country to country, depending upon the tradition, culture, and educational levels of the people at large.

Educational policies seem to have been made in accordance with the policy and political system of a particular country, as was clearly noted by Cohen et al. (1974) when he stated, "What you want in the country you put in the school." Their idea seems to be the basis of political influence on the overall affairs of higher education and not just on decision making. Politicians' interest in influencing the decision making of a higher educational Organization appears to 
TRIBHUVAN UNIVERSITY JOURNAL, VOL. XXIV, NO. 1,

be guided by this basic approach. Similarly, Massialas (1969) mentioned that the political influence that affects higher education decision-making can easily be seen when the institution is governed by local authorities. In addition, the economic, political, and historical contexts of higher education institutions can also play important roles in influencing the decision-making of higher education.

In the same way, influence on decision-making at the university also depends upon the organizational structure of the university. If one assumes that the university is a complex political organization, as Kogan (1984) viewed it, one would find the greater role of politics to influence decision-making of it. Kogan conceived of a university, and other institutions of higher education, as intensely politically complex units, where the line of bureaucratic authority and the line of political influence merge with each other. Therefore, some universities in some contexts work like bureaucratic organizations, and some other universities in some other contexts act like complex political organizations (Birnbaum, 1988). In Birnbaum's view, external politics, armed with power gained through political legitimacy, are able to buy desired goods are purchased by the payment of required amount of money.

The structure of a university Organization is such that the higher-level decision-making authority is in the hand of a chief executive of the institution. It is bureaucratic internally, but under great control externally. If one were to assume administrative features in a bureaucratic structure of higher education (Birnbaum, 1988), Tribhuvan University administration appears to be tightly coupled internally and loosely coupled externally.

Bergquist (1992) perceived that political influence or even intervention on the university decision-making to be something necessary if the government thinks the decisions and the working procedures of the university are irreparably damaging, or if the university shows a disregard to the proper norms of its own. This could be either, for example, in the decisions regarding handling of university finances, or the appointment and the promotion of faculty, or the admission of students. Thus, the university organization works more like a bureaucratic organization than a political one, where central administrative authority is more powerful and influential. Therefore, even if there is a role of politics in the decision-making at the university, this role is due to the very nature of the university itself, which is tightly coupled bureaucratically inside and loosely coupled to the politics externally (Bergquist, 1992). All this is because, often times, university creates such an environment by itself where it becomes convenient or even necessary for outside politics to influence, control, or intervene in university decisions. Therefore, the university, that teaches every generation of students how to address the challenges in building the nation, is now in a position to learn how best it could perform its job in shaping the builder of a nation.

\section{WORKS CITED}




\section{POLITICAL INFLUENCE: A CULTURE IN UNIVERSITY}

Baldridge, J.V., \& Riley, L.G. (1977). Governing academic organization. Berkely, CA: McCutchan Publishing Corporation.

Bergquist, H.W. (1992). The four cultures of the academy. San Francisco: JOssey-Bass.

Birnbaum, R. (1988). How colleges work: The cybernetics of academic organization and leadership. Boston: Jossey Bass.

Cohen, M..D., \& March, J.G. (1974). Leadership and Ambiguity. New York: McGraw Hill.

Hosfstede Geert (1991). Cultures and Organizations: Software of mind. New York: McGraw Hill.

Karol, H.N., \& Ginsburg, G.S. (1980). Managing the higher education enterprise. New York: Ronald Press.

Kogan, M. (1984). "The political view." In C.R. Burton (ed.), Perspectives on higher education. Los Angeles, CA: University of California Press.

Livingstone, H. (1974). The university: An organizational analysis. London: Blakie \& Sons.

MacKinnon, F. (1965). The politics of education: A study of the political administration of the public schools. Toronto, Canada: University of Toronto Press.

Massialas, G.B. (1969). Education and the political system. Reading, MA: Addison-Wesley.

Rudolph, H.S., \& Rudolph, I.L. (1972). Education and politics in India. Cambridge, MA: Harvard University Press. 